\title{
Does the Global Financial Crisis Matter for the Macro Economic Performance of Inflation Targeting in Advanced and Developing Countries?: A Panel Study
}

\author{
Enflasyon Hedeflemesi ve Kriz: Geliş̧miş ve Geliş̧mekte olan Ülkelerin \\ Makroekonomik Performanslarının Panel Veriler Yaklaşımı Kullanılarak Analizi
}

\author{
Assoc. Prof. Dr. Metin Özdemir - Asst. Prof. Dr. Selim Tüzüntürk
}

\begin{abstract}
Inflation targeting has come under sharp attack in the aftermath of the global financial crisis. In this paper we compare the macroeconomic performances of advanced and developing inflation targeting countries before and after the global financial crisis. Using a panel data methodology, we assess the effectiveness of the inflation targeting framework in both country groups when confronting a serious shock. Our results demonstrate that developing inflation targeting countries seem to have performed better in handling the global financial crisis and to have outperformed their advanced peers in the aftermath of the crisis. We argue that the performance of developing inflation targeting countries has arisen from an inflation targeting framework and countercyclical fiscal policy. The global financial crisis also reveals that price stability is not enough to secure financial stability and growth. The main issue for the future of inflation targeting is to incorporate financial stability.
\end{abstract}

Keywords: Inflation Targeting, Global Financial Crisis, Macroeconomic Performance, Panel Data Analysis

\section{Öz}

Enflasyon hedeflemesi küresel finansal krizin ardindan keskin eleştirilere uğradr. Bu makalede, enflasyon hedeflemesi uygulayan gelişmiş ve gelişmekte olan ülkelerin küresel finansal kriz öncesi ve sonrasinda makroekonomik performanslarını karşılaştırıyoruz. Her iki ülke grubu itibariyle, ciddi bir şokla karşılaşıldığında enflasyon hedeflemesinin ne düzeyde etkin bir politika olduğunu, panel veri yöntemini kullanarak, değerlendiriyoruz. Sonuçlarımız, enflasyon hedeflemesi uygulayan gelişmekte olan ülkelerin, gelişmiş ülkelere nazaran krizle daha olumlu başa çıkabildiklerini ve krizin ardindan daha yüksek makroekonomik performans gösterdiklerini ortaya koymuștur. Enflasyon hedeflemesi uygulayan gelişmekte olan ülkelerin gösterdiği makroekonomik performansta, enflasyon hedeflemesi ve konjonktür karşıtı mali politika tepkilerinin rol oynadığı görülmüștür. Bu bağlamda, küresel finansal kriz tek başına fiyat istikrarının sağlanmasının finansal istikrar ve büyüme için yeterli olmadiğını göstermiştir. Enflasyon hedeflemesinin geleceği açısından temel sorun ise, enflasyon hedeflemesinin finansal istikrarı içerecek şsekilde genişletilmesidir.

Anahtar Kelimeler: Enflasyon Hedeflemesi, Küresel Finansal Kriz, Makroekonomik Performans, Panel Veri Analizi

\section{Introduction}

Since the beginning of the 1990s, both advanced and developing countries have adopted inflation targeting (IT) as their monetary policy framework. The basic principle of conducting monetary policy within this regime is to adjust the policy interest rate to keep the inflation forecast close to the inflation target and to

Assoc. Prof. Dr. Metin Özdemir, Uludağ University Faculty of Economics and Administrative Science, mozdemir@uludag.edu.tr Asst. Prof. Dr. Selim Tüzüntürk, Uludağ University Faculty of Economics and Administrative Science, selimtuzunturk@uludag.edu.tr 
achieve price stability as the primary objective of monetary policy. IT also involves some institutional features such as central bank independence, transparency and accountability to improve the effectiveness and credibility of monetary policy. Advocates of this framework claim that IT provides a guide for expectations, reduces long-run inflation and promotes stability and sustainable growth (Bernanke et.al., 1999, pp.297-299; Truman, 2003, pp.71-98). By the end of 2010 , there were 26 advanced and developing countries that officially used IT (Roger, 2010, pp.25-56), and many other countries are on the way to establishing this framework. Therefore, it is argued that IT with floating exchange rates provides a stable international monetary system that is considered to be a reversed Bretton Woods (Rose, 2007, pp.663-681).

Although IT has gained widespread acceptance, the Global Financial Crisis (GFC) that began in the USA in August 2007 triggered considerable debate concerning the conduct of monetary policy under IT. Whether there have been significant macroeconomic performance differences in stability and growth compared with the non-IT countries remains an important debate in both academic and central bank circles. In the two decades before the crisis, there was a disinflation and growth period in the world economy labelled the Great Moderation (Bernanke, 2004), or the Golden Years of Central Banking (Gerlach et al., 2009, p.1). The Great Moderation reflected the New Consensus in Macroeconomics (NCM) between the New Classical/Real Business Cycle theory and the New Keynesian Economic theory regarding the analysis of business cycles and the design of optimal policies (Clarida et al., 1999, pp.1661-1707; Blanchard, 2009, pp.209-228). As part of this consensus, IT identifies the best practices and the state of the art for monetary policy and the main policy instrument of the NCM (Arestis, 2012, pp.196-208; Issing, 2012, pp.55-74).

Throughout the Great Moderation period, during which IT was widely adopted, it has been emphasised that IT was introduced under relatively benign macroeconomic conditions and that the shocks hitting the economy were mild (Stock and Watson, 2003, pp.9-56). Therefore, IT was not tested with major shocks. Accordingly, the performance of IT countries was due to the good luck brought by the Great Mode- ration period, rather than a good policy characterised by IT (Ball and Sheridan, 2005, pp.249-282; Rasche and Williams, 2007, pp.447-489). Until mid-2007, there was less scepticism about the resilience of IT and little reason to abandon this framework. However, the GFC marked the end of the Great Moderation, and the policy framework based on the NCM is now seen as having failed (Buiter, 2009; Stiglitz, 2011, pp.591-645; Arestis and Sawyer, 2013, pp.1-17). The debate over the causes and dynamics of the GFC highlighted the role and responsibilities of price stability-oriented policies under IT (Hume and Sentance, 2009, pp.1426-1461; O'Hara, 2011, pp.1-17). The main criticism of the IT framework after the crisis is that by requiring central banks to focus on price stability, it ignores financial stability (Ito 2010; Wagner, 2010, pp.63-82). However, the crisis made it clear that price stability does not guarantee financial stability and growth (Borio, 2011).

The failure of the IT framework based on the NCM and the recognition of the importance of financial stability has led to a questioning of IT. As Blanchard et al. (2010) stated after the crisis "... we knew how to conduct macroeconomic policy. The crisis clearly forces us to question that assessment". Some authors and policymakers announced the death of IT and recommended abandoning it, instead proposing an alternative framework such as nominal GDP targeting (Stiglitz, 2008 ; Carney 2012; Frankel 2012) or financial stability as a goal of monetary policy (Arestis and Sawyer, 2010, pp.499-515). Opponents of IT from academics and policy makers argued that the correct answer to the crisis is to improve IT by incorporating financial stability (King 2009; Mishkin 2011; Walsh, 2011, pp.23-36). Contrarily, Svensson (2009), a founding father of the IT framework, still considered IT to be the optimal monetary policy: “... flexible inflation targeting... using all the information about financial factors that is relevant for the forecast of inflation... remains the best-practice monetary policy before, during, and after the financial crisis".

This paper considers the above discussion as its starting point and attempts to investigate the comparative performances of advanced and developing countries which implement an IT framework. The paper has two main objectives. The first objective is to analyse the macroeconomic performance differences under 
IT in both country groups before and after the GFC. The second objective is to evaluate the effectiveness of the IT framework in both country groups when confronted with a serious shock. Unlike previous literature, we compare the performance of advanced and developing IT countries, rather than IT and non-IT countries. To assess the performance of IT countries, alternative panel data models were estimated for the pre- and post-crisis periods. Our results show that developing IT countries seem to have performed better in handling the GFC, even outperforming their advanced peers in the aftermath of the crisis.

The remainder of the paper is structured as follows. Section 2 presents the debate over IT before and after the GFC and the literature concerning the macroeconomic performance of IT in advanced and developing countries. Section 3 describes the data and methodology. The empirical results are given in Section 4 , and the last section presents the conclusions.

\section{The Global Financial Crisis and The Inflation Targeting Debate}

The criticism of IT before the GFC indicated that the macroeconomic performance of IT countries was not superior to that of non-IT countries. Opponents of the IT framework assert that IT tends to place an increased focus on inflation and is not concerned with output fluctuations; it also provides less flexibility to respond to unforeseen shocks or changes in the structure of the economy. Therefore, IT countries were able to reduce inflation volatility at the cost of greater output instability (Cecchetti and Ehrmann, 2002, pp.247-274; Friedman, 2004, pp.1-12). In response to these criticisms, IT proponents argue that IT provides enough flexibility to respond to output or employment changes. When inflation expectations are well anchored, IT creates greater credibility and manoeuvrability for monetary policy against various shocks hitting the economy (Svensson, 2002, pp.261312; Walsh, 2009, pp.195-233).

There are a number of studies with varying results that have aimed to estimate the effects and macroeconomic performance of IT. These studies seek to evaluate the effectiveness of IT over alternative monetary frameworks and to compare the macroeconomic performances of IT and non-IT countries. Some important findings to emerge from empirical studies of IT performed before the GFC can be summarised. IT countries have been successful in achieving and maintaining low inflation rates (Vega and Winkelried, 2005, pp.153-175; Mishkin and Schmidt-Hebbel, 2007, pp.291-372; Mendonça, 2007, pp.573-576). As previously mentioned, some authors have attributed this finding on the Great Moderation period to the coinciding of the widespread adoption of IT with a period of historically low inflation and output volatility (Ball and Sheridan, 2005, pp.249-282; Dueker and Fischer, 2006, pp.431-450; Willard, 2011, pp.22312244). In addition to these results, there were no differences between IT and non-IT countries in terms of lower inflation rates, well-anchored and accurate inflation expectations and there was no significant evidence that IT bolstered credibility (Angeriz and Arestis, 2008, pp.293-317; Lanzafame and Nogueira Jr., 2011, pp.1080-1098). Contrarily, some authors have shown that output volatility has not changed or worsened after the adoption of IT and IT countries suffered smaller output losses during disinflations when compared to non-IT countries (Arestis et al., 2002, pp.528-545; Goncalves and Carvalho, 2009, pp.233-243). Moreover, the persistence of inflation has decreased, and inflation expectations appear to be more anchored in IT countries compared to non-IT countries (Johnson, 2002, pp.1493-1519; Levin et al., 2004, pp.51-80; Gürkaynak et al., 2007, pp.415-465).

These findings indicate that the empirical evidence on the performance of IT is not unanimous, which is explained by the differences in the selection of comparator countries and the endogeneity of the decision to adopt IT (Roger, 2010, pp.25-56). More recently, there has been empirical evidence on the performance of IT in developing countries (International Monetary Fund (IMF) 2005, pp.161-186; Batini and Laxton, 2007, pp.467-506; Gonçalves and Salles, 2008, pp.312-318; Lin and Ye, 2009, pp.118-123; Lee, 2011, pp.375-397; Broto, 2011, pp. 1424-1434). To avoid endogeneity problems, these studies have employed various empirical strategies, such as difference-indifferences and propensity score matching methods. The findings of these studies provide support for the view that IT dominates other monetary policy frameworks, and to some extent, its performance can be attributed to the framework itself. Developing countries adopting the IT framework experienced lower 
inflation, lower inflation expectations and lower inflation volatility, as well as lower volatility of interest rates, exchange rates, international reserves and output growth when compared with countries that have not adopted it.

Contrarily, recent empirical studies on the performance of IT in advanced countries have indicated that IT caused no significant improvement in their macroeconomic performance and the effects of IT were weak (Lin and Ye, 2007, pp. 2521-2533; Ball, 2010; Mendonça and Souza, 2012, pp. 178-191). These results may lead to the conclusion that IT has only improved macroeconomic performance among developing countries and that it did not impact advanced countries. However, the period of Great Moderation coincided with the adoption of IT, making it difficult to isolate any distinct contribution of this framework. As noted by Walsh (2009), "...it may be difficult to distinguish a unique contribution of IT to inflation behavior among high-income countries is that virtually all of them follow policies that could be described as inflation targeting". Therefore, the similar macroeconomic performance among countries with or without IT is not surprising, and the choice regarding IT is clearly a result of the country's own macroeconomic and institutional environment (Krause and Mendez, 2008, pp.282-307; Samaryna and Haan, 2011).

While the evidence on whether IT countries outperform non-IT countries is inconclusive, a new debate emerged on the resilience of this framework by the end of the Great Moderation with the GFC. In regard to assessing the origins of the crisis, among the other contributing factors, there were two opposing views on interpreting the crisis. According to the first view, low interest rates resulting from a lax monetary policy, particularly that practiced by the Federal Reserve (Taylor, 2009, pp.341-364) and an IT framework that narrowly focused on price stability were the main factors responsible for the crisis (Grauwe, 2007; Leijonhufvud 2008). An IT framework engenders significant risks to financial stability either by fostering lower real interest rates that trigger higher asset prices or by encouraging central banks to ignore the build-up of financial imbalances (Borio and White, 2004). Frappa and Mésonnier (2010) affirm this view and empirically show that the adoption of IT is associated with an increase in the real house price and price-to-rent ratio.
In response to the first view, the second view interpreted the crisis first and foremost as a failure of regulation and supervision and asserted that IT should not be blamed (Posen, 2009, pp.115-122; Svensson, 2010; Woodford, 2012, pp.7-32). The ineffectiveness of financial regulation and a lack of supervision were the main factors responsible for the crisis that had very little to do with IT (Ito 2010; Louis and Balli, 2013, pp. 546-564).

One of the main arguments in favor of IT before the crisis was its resilience and the widespread assumption that once a country switched to IT, it stuck to this framework. As Bernanke (2003) stated: "Central banks that have switched to inflation targeting have generally been pleased with the results they have obtained. The strongest evidence on that score is that, thus far at least, none of the several dozen adopters of inflation targeting has abandoned the approach". However, the Central Bank of Iceland was the first central bank to formally suspend IT after the crisis (Gudmundsson, 2010). Recently, although the Swiss National Bank is not a self-declared inflation targeter, it has abandoned its earlier implicit IT by moving to exchange rate targeting (Hildebrand, 2011). Contrary to these central banks, the United States and Japan have adopted numerical inflation objectives and have taken substantial steps toward IT (Bullard, 2012; Bank of Japan 2012; Federal Open Market Committee 2012). From the perspective of developing countries, no one has abandoned an IT framework in the aftermath of a crisis. Furthermore, recent research suggests that developing countries fared substantially better than advanced countries during the GFC (Claessens et al., 2010, pp.267-293; Lane and MilesiFerretti, 2010; Rose and Spiegel, 2011, pp.309-324; Didier et al., 2012, pp.2052-2077).

With regard to the differing performances of advanced and developing countries during the GFC, it is worth considering the performance of IT in these countries. As mentioned above, there were many studies that explored the macroeconomic performance of IT, but there is a relative dearth of literature engaging the performance of IT when facing a shock. Before the GFC, Neumann and Hagen (2002) compared the performance of IT and non-IT central banks during the oil price hikes of 1978 and 1998. Using the difference in difference approach, their results indicated that IT countries realised a credibility gain in the 
second episode compared to the first, allowing them to keep interest rates lower and to face these shocks with a much less contractionary monetary policy. Mishkin and Schmidt-Hebbel (2007) also used impulse response functions and panel VAR (vector autoregressive ) techniques to investigate whether IT countries and non-IT countries differ in the response of inflation to shocks in oil prices and the response of domestic interest rates to innovations in international interest rates. They found that IT helped to reduce the domestic inflation response to an oil price shock and that the response of the domestic interest rate to international interest rate shocks decreased substantially for IT countries, which reflected their monetary policy independence.

To the best our knowledge, Filho (2011) and Primus and Mahabir (2011) are the only studies which empirically analyse whether IT countries outperformed non-IT countries during the GFC. To compare the performance of IT and non-IT countries during the crisis, Filho (2011) scrutinised 51 advanced and developing countries, of which 23 are inflation targeters. To provide this comparison, he uses a simple econometric framework on a panel data set of macroeconomic variables by countries. Although Filho (2011) finds no differences in unemployment dynamics, IT countries (and flexible exchange rate regime) have fared better than non-IT countries in terms of GDP growth and industrial production in the two years since the crisis began. Also the monetary policy of IT countries appears to be better suited to address the crisis. Drawing on the work by Filho (2011), Primus and Mahabir (2011) investigate the performance of 6 IT and 24 non-IT countries in the Latin American and Caribbean Region by employing a panel data set for the period of 2007-2010. Their results indicate that IT countries did not have superior growth performance and the IT framework is not geared toward the adverse effects of the crisis.

All of the studies mentioned above focused on the issue of how IT countries have performed compared to non-IT countries and whether IT has made a significant difference. In this study, however, due to the different performances of advanced and developing countries in the aftermath of the GFC, we compare the performances of advanced and developing IT countries to discern how IT has performed in both country groups before and after the GFC.

\section{Data and Methodology}

When constructing the sample, we referred to Roger (2010). Countries covered in this study include those that had already adopted full-fledged IT before the GFC. We included New Zealand (1990), Canada (1991), the United Kingdom (1992), Sweden (1993), Australia (1993) and Norway (2001) as advanced IT countries. The developing IT countries are Israel (1997), The Czech Republic (1997), Poland (1998), Brazil (1999), Chile (1999), Colombia (1999), South Africa (2000), Thailand (2000), Mexico (2001), South Korea (2001), Hungary (2001), Peru (2002), the Philippines (2002) and Turkey (2001). Thus our data set included 6 advanced IT and 14 developing IT countries examined for the years 2001 to 2011. The sample periods are split into two periods as the pre-crisis (2001-2006) and post-crisis (2007-2011) periods. We used 2007 as the starting date of the post-crisis period to capture the global commodity price shock. We excluded Iceland, which suspended the IT framework during the crisis, and those countries that adopted IT in the midst of our analysis period - Indonesia, Romania, Slovakia and Guatemala in 2005; Serbia in 2006; Ghana in 2007 - to avoid selection bias. One country, Turkey, was included because, although it only officially adopted full-fledged IT in January 2006, the Central Bank of the Republic of Turkey announced an implementation of implicit IT after the February 2001 financial crisis. Most of the data are drawn from the IMF financial statistics website. Some missing data were taken from relevant countries' central bank web sites. All of the data denote annual percentage change.

To compare the performance of advanced and developing IT countries, we use panel data methodology. This methodology enables us to make inferences about IT countries as a whole. Panel data are the same cross section data that are observed over time (Gujarati, 2003, p.636). Panel data provide information on individual behaviour both across time and across individuals (Cameron and Trivedi, 2006, p.698). Panel data involve two dimensions: a cross-sectional dimension $\mathrm{N}$, and a time-series dimension $\mathrm{T}$ ( $\mathrm{Hsi}-$ ao, 2003, p.7). Panel data variables are symbolised by two subscripts $\left(y_{i t} y_{i t}\right)$, where the first subscript, " $i i$ " refers to the entity being observed $(i=1, \ldots . . N$ $i=1, \ldots . N)$ and the second subscript " $t t$ " refers 
to the date $(t=1, \ldots \ldots . T t=1, \ldots \ldots . T)$ at which it is observed (Stock and Watson, 2007, p.350).

For each panel data variable there are NTNT data points. The availability of the data in both dimensions enables us to consider the individual differences between cross sections and time differences between periods, or both.

Random effect models (RE) and fixed effect models (FE) are the main panel data models. RE model can be an appropriate specification if we are executing a random sampling procedure (Erlat, 1997, p.11).

When $N N$ individuals are drawn from a large population, the RE model is more appealing (Mátyás and
Sevestre, 1996, p.31). The FE model is an appropriate specification when we are focusing on a specific set of $N N$ individuals as in this study. Here, we focus on the following FE models.

In the panel data approach, the ordinary least-squares (OLS) model, also called the pooled regression model, is tested against alternative FE models (FE Model with Individual Effects, FE Model with Time Effects and FE Model with both Individual and Time Effects) using $\mathrm{F}$ tests to determine the most appropriate specification. By using our dependent and independent variables, OLS model and alternative FE models are shown in Table 1.

Table 1. OLS Model and Alternative FE Models

\begin{tabular}{|l|l|}
\hline \multicolumn{1}{|c|}{ Model } & \multicolumn{1}{c|}{ Equation } \\
\hline OLS Model & $y_{i t}=\alpha+\beta_{i t} I T C+\varepsilon_{i t}$ \\
\hline FE Model with Individual Effects & $y_{i t}=\alpha_{i}+\beta_{i t} I T C+\varepsilon_{i t}$ \\
\hline FE Model with Time Effects & $y_{i t}=\alpha_{t}+\beta_{i t} I T C+\varepsilon_{i t}$ \\
\hline FE Model with both Individual and Time Effects & $y_{i t}=\alpha_{i}+\alpha_{t}+\beta_{i t} I T C+\varepsilon_{i t}$ \\
\hline
\end{tabular}

Here, $y_{i t} y_{i t}$ is the dependent variable of interest. We used different dependent variables in each different estimation attempt. The dependent variables are inflation (INF), policy rates (PRATE), gross domestic product (GDP), unemployment (UNEMP) and current account balance (CAB).

The independent variable is IT country, and it is symbolised by ITCITC. In contrast to the various dependent variables, we used the same independent variable in each different estimation attempt. If the country is an advanced IT country, then ITCITC assumes the value of one " 1 ", and if the country is a developing IT country, then ITCITC assumes the value of zero "0". The coefficient of ITCITC that is symbolised by $\beta_{i t} \beta_{i t}$ measures the difference in the variable $y_{i t} y_{i t}$ between advanced and developing IT countries. $\alpha$ is the common intercept, $\alpha_{i} \alpha_{i}$ is a country-specific effect, $\alpha_{t} \alpha_{t}$ is a time effect, and $\varepsilon_{i t}$ $\varepsilon_{i t}$ is an idiosyncratic shock.

\section{Results}

After the pooled regression model was tested against alternative FE models with $\mathrm{F}$ tests, more appropriate models were found for each one of the different dependent variables. The results for the pre-crisis period (2001-2006) and the post-crisis period (20072011) are respectively shown in Table 2 and 3. 
Table 2. Model Estimations for the Pre-Crisis Period

\begin{tabular}{|c|c|c|c|c|c|}
\hline $\begin{array}{c}\text { Model } \\
\mathbf{1}\end{array}$ & Best Fitted Model & $\begin{array}{c}\text { Dependent } \\
\text { Variable }\end{array}$ & $\widetilde{\boldsymbol{\beta}}$ & $\boldsymbol{R}^{2}$ & $\begin{array}{c}\boldsymbol{D} \boldsymbol{W} \\
\text { Statistic }\end{array}$ \\
\hline $\begin{array}{c}\text { Model } \\
\mathbf{2}\end{array}$ & Pooled (Period Sur) & INF & $\begin{array}{c}-1.52 \\
(0.13)\end{array}$ & 0.02 & 2.14 \\
\hline $\begin{array}{c}\text { Model } \\
\mathbf{3}\end{array}$ & $\begin{array}{c}\text { Fixed Time Effect } \\
\text { (Period Sur) }\end{array}$ & GDP & $\begin{array}{c}-1.35 \\
(0.32)\end{array}$ & 0.08 & 2.07 \\
\hline $\begin{array}{c}\text { Model } \\
\mathbf{4}\end{array}$ & $\begin{array}{c}\text { Pooled (Period Sur) } \\
(0.00)^{*}\end{array}$ & UNEMP & $\begin{array}{c}-3.69 \\
(0.02)^{* *}\end{array}$ & 0.49 & 1.99 \\
\hline $\begin{array}{c}\text { Model } \\
\mathbf{5}\end{array}$ & Pooled (Period Sur) & CAB & $\begin{array}{c}1.94 \\
(0.26)\end{array}$ & 0.02 & 1.95 \\
\hline
\end{tabular}

Note: Probability values (p-values) are shown in parentheses. ${ }^{*}$ denotes that the parameter is significant at the $1 \%$ significance level; ${ }^{* *}$ denotes the parameter is significant at the $5 \%$ significance level. Period Sur: Period Seemingly Unrelated Regression.

Among these models, $\widehat{\boldsymbol{\beta}} \widehat{\boldsymbol{\beta}}$ is statistically significant at the $1 \%$ level in Model $3(\mathrm{p}<.01)$ and at the $5 \%$ level in Model 4 ( $\mathrm{p}<$.05). In these models $\widehat{\boldsymbol{\beta}} \widehat{\boldsymbol{\beta}}$ were found with negative signs (respectively; -1.44 and -3.69 ). On the other hand, $\widehat{\boldsymbol{\beta}} \widehat{\boldsymbol{\beta}}$ were found to be statistically insignificant for Models 1,2 and 5 ( $\mathrm{p} \geq .05)$. The de- termination coefficients of all models range between 0.02 and 0.85 (see column 5 in Table 2). Additionally, the Durbin Watson (DW) statistics are satisfactorily close to the Durbin-Watson value of $d=2$, which indicates that there are no first-order serial correlations in the residuals for all models above (see column 6 in Table 2).

Table 3. Model Estimations for the Post-Crisis Period

\begin{tabular}{|c|c|c|c|c|c|}
\hline & $\begin{array}{c}\text { Best Fitted } \\
\text { Model }\end{array}$ & $\begin{array}{c}\text { Dependent } \\
\text { Variable } \\
\end{array}$ & $\widetilde{\boldsymbol{\beta}}$ & $R^{2}$ & $\begin{array}{c}D W \\
\text { Statistic }\end{array}$ \\
\hline Model 6 & $\begin{array}{c}\text { Fixed Time } \\
\text { Effect } \\
\text { (Period Sur) }\end{array}$ & INF & $\begin{array}{l}-2.09 \\
(0.00)^{*}\end{array}$ & 0.36 & 1.97 \\
\hline Model 7 & $\begin{array}{c}\text { Fixed Time } \\
\text { Effect } \\
\text { (Period Sur) }\end{array}$ & PRATE & $\begin{array}{l}-1.70 \\
(0.02) * *\end{array}$ & 0.61 & 1.90 \\
\hline Model 8 & $\begin{array}{c}\text { Fixed Time } \\
\text { Effect } \\
\text { (Period Sur) }\end{array}$ & GDP & $\begin{array}{l}-2.61 \\
(0.00)^{*}\end{array}$ & 0.80 & 1.97 \\
\hline Model 9 & $\begin{array}{c}\text { Pooled } \\
\text { (Period Sur) }\end{array}$ & UNEMP & $\begin{array}{l}-3.38 \\
(0.07)\end{array}$ & 0.34 & 1.97 \\
\hline $\begin{array}{c}\text { Model } \\
10\end{array}$ & $\begin{array}{c}\text { Pooled } \\
\text { (Period Sur) }\end{array}$ & CAB & $\begin{array}{l}1.31 \\
(0.49)\end{array}$ & 0.004 & 1.92 \\
\hline
\end{tabular}

Note: Probability values (p-values) are shown in parentheses. ${ }^{*}$ denotes that the parameter is significant at the $1 \%$ significance level; ${ }^{* *}$ denotes the parameter is significant at the $5 \%$ significance level. Period Sur: Period Seemingly Unrelated Regression. 
Among these models, $\widehat{\boldsymbol{\beta}} \widehat{\boldsymbol{\beta}}$ is statistically significant at the $1 \%$ level in Models 6 and $8(\mathrm{p}<.01)$ and at the $5 \%$ level in Model 7 ( $\mathrm{p}<.05)$. In Models 6, 8, and 7, $\widehat{\boldsymbol{\beta}}$ $\widehat{\boldsymbol{\beta}}$ were found to have negative signs $(-2.09,-2.61$ and -1.70, respectively). However, $\widehat{\boldsymbol{\beta}} \widehat{\boldsymbol{\beta}}$ were found to be statistically insignificant for Models 9 and $10(\mathrm{p} \geq .05)$.
The determination coefficients of all the models range between 0.004 and 0.80 (see column 5 in Table 3). The Durbin Watson (DW) statistics are close enough to the Durbin-Watson value of $d=2$, which indicates that there are no first-order serial correlations in the residuals for all the models listed above (see column 6 in Table 3).

Table 4. Comparisons of Estimations for Both Periods

\begin{tabular}{|c|c|c|}
\hline Dependent Variable & $\begin{array}{c}\widehat{\boldsymbol{\beta}} \\
\text { for pre-crisis } \\
\text { period }\end{array}$ & $\begin{array}{c}\widehat{\boldsymbol{\beta}} \\
\text { for post-crisis } \\
\text { period }\end{array}$ \\
\hline INF & -1.52 & -2.09 \\
$(0.13)$ & $-1.00)^{*}$ \\
\hline \multirow{2}{*}{ PRATE } & -1.35 & $(0.02)^{* *}$ \\
\hline \multirow{2}{*}{ GDP } & $(0.32)$ & -2.61 \\
& -1.44 & $(0.00)^{*}$ \\
\hline \multirow{2}{*}{$\mathrm{UNEMP}$} & $(0.00)^{*}$ & -3.38 \\
& -3.69 & $(0.07)$ \\
\hline \multirow{2}{*}{$\mathrm{CAB}$} & $(0.02)^{* *}$ & 1.31 \\
& 1.94 & $(0.49)$ \\
\hline
\end{tabular}

Note: Probability values (p-values) are shown in parentheses. * denotes that the parameter is significant at the $1 \%$ significance level; ${ }^{* *}$ denotes the parameter is significant at the $5 \%$ significance level.

Models with INF dependent variables' $\widehat{\boldsymbol{\beta}} \widehat{\boldsymbol{\beta}}$ value were found to be statistically insignificant for the precrisis period and statistically significant for the postcrisis period. This means that, while a significant difference was not found in the mean inflation for the pre-crisis period between advanced and developing IT countries, a significant difference was found in the mean inflation for the post-crisis period between these country groups. As mentioned before, countries have generally experienced price stability and growth in the pre-crisis period. However, with the surge in food and energy prices in 2007 and the first half of 2008 most IT countries overshot their official inflation targets. Faced with an increase in inflation, central banks tightened monetary policy but that expectations remained within the target range in most IT countries. Additionally, this means that medium and long-term expectations remained well-anchored (Habermeier et al., 2009; Roger, 2010, pp.25-56). As for inflation, the negative estimated coefficient of $\widehat{\boldsymbol{\beta}} \widehat{\boldsymbol{\beta}}$ for the post-crisis period $(-2.09)$ indicates that developing IT countries outperformed their more-advanced peers. This result reflects the credibility of the IT framework in developing countries and reveals that these countries seem to have performed better than advanced IT countries in managing inflation volatility in the aftermath of the crisis.

Models with PRATE dependent variables' $\widehat{\boldsymbol{\beta}} \widehat{\boldsymbol{\beta}}_{\text {va- }}$ lue were found to be statistically insignificant for the pre-crisis period and statistically significant for the post-crisis period. With regards to PRATE, $\widehat{\boldsymbol{\beta}}$ these results show that, while a significant difference was not found in the mean policy rates between advanced and developing IT countries for the pre-crisis period, a significant difference was found in the mean policy rates between these country groups in the post-crisis 
period. Contrary to the low interest rates and financial stability environment before the crisis, IT countries had tight monetary policies and high interest rates due to the surge in commodity prices in the early phase of the crisis. As the crisis deepened, these countries eased their monetary policy stances and cut their policy rates.

One of the main arguments about the positive performance of IT countries relative to their non-IT peers in the aftermath of the crisis was that higher interest rates helped IT countries to better cope with the crisis by providing more manoeuvrability to reduce their policy rates and therefore less need for costly extraordinary fiscal measures (Filho, 2011, pp.1-44). Additionally, credible IT frameworks have played an important role in avoiding persistent deflation (Decressin and Laxton, 2009). These arguments are particularly valid for developing IT countries. Accordingly, considering the policy rates, a negative estimated coefficient of $\widehat{\boldsymbol{\beta}} \widehat{\boldsymbol{\beta}}$ for the post-crisis period (-1.70) means that developing IT countries outperformed advanced IT countries. Higher interest rates have allowed developing IT countries to follow more aggressive courses of monetary policy easing without threatening their inflation outlooks, and these countries have avoided deflation better than have advanced IT countries. Siklos (2010) has argued that IT has contributed to a more disciplined monetary policy, and this was the evidence of resilience of IT in developing countries in the aftermath of the crisis.

Conversely, advanced countries (i.e., Canada and the United Kingdom) have decreased their policy rates very close to zero and have faced a liquidity trap and zero lower bound on interest rates. When the policy rate is reduced close to zero, conventional monetary policy loses its effectiveness (Borio and Disyatat 2009). As mentioned before, the risk of deflation and undershooting the inflation target has led advanced IT countries to rely heavily on unconventional monetary policies to address financial instability. Considering the policy rates, although developing IT countries seem to have performed better than their advanced peers in the aftermath of the crisis, monetary easing in advanced countries generally forced developing IT countries to modify their IT frameworks by using some macroprudential measures to avoid the destabilising effects of credit growth and capital flows. This allowed them to maintain price and financial stability (Ostry et al., 2012, pp.407-421).
Models with GDP dependent variables' $\widehat{\boldsymbol{\beta}} \widehat{\boldsymbol{\beta}}$ value were found statistically significant for both periods. This means that a significant difference was found in the mean GDP for both periods between advanced and developing IT countries. Negative estimated coefficients of $\widehat{\boldsymbol{\beta}} \widehat{\boldsymbol{\beta}}$ (-1.44 and -2.61) indicate that developing IT countries outperformed advanced IT countries in both periods. As mentioned above, due to the zero lower bound on nominal interest rates, monetary policies could not provide appropriate stimuli to restore growth in advanced IT countries. While countries cut policy rates substantially, governments announced strong countercyclical fiscal policies by increasing expenditure and lowering taxes to offset the decline of aggregate demand. According to Blanchard et al. (2010) and Filho (2011), countries with lower debt in the pre-crisis period have been relatively less affected by the GFC. With the absence of the fiscal dominance for the effectiveness of IT and better fiscal conditions in the previous years, developing IT countries had more fiscal space than advanced IT countries (Didier et al., 2012, pp.2052-2077; IMF, 2012, pp.129-171). As the magnitude of the estimated coefficients of $\widehat{\boldsymbol{\beta}} \widehat{\boldsymbol{\beta}}_{\text {(-1.44 for pre-crisis period and }-2.61}$ for post crisis period ) reveals, that monetary policy easing combined with expansionary fiscal policy has improved the performance of developing IT countries significantly relative to their advanced peers in the post-crisis period.

Models with UNEMP dependent variables, $\widehat{\boldsymbol{\beta}} \widehat{\boldsymbol{\beta}}_{\text {va- }}$ lue were found to be statistically significant for the pre-crisis period and statistically insignificant for the post-crisis period. These results show that while a significant difference was found in the mean unemployment between advanced and developing ITIT countries for the pre-crisis period, a significant difference was not found in the mean unemployment between these country groups for the post-crisis period. A negative estimated coefficient of $\widehat{\boldsymbol{\beta}} \widehat{\boldsymbol{\beta}}$ for the pre-crisis period $(-3.69)$ indicates that developing IT countries had superior unemployment performances during the Great Moderation compared to their advanced peers. However, the GFC has sharply increased unemployment in both groups of countries. Despite the easing of monetary policies and despite aggressive fiscal stimulus, advanced IT countries exhibited much higher levels of unemployment than 
usual. Although developing IT countries have recovered from the crisis, their unemployment rates remained persistently high.

\section{Models with $\mathrm{CAB}$ dependent variables' $\widehat{\boldsymbol{\beta}} \widehat{\boldsymbol{\beta}}$ value} were statistically insignificant for both periods. The results show that there was no significant difference in the mean current account balance between advanced IT countries and developing IT countries for both periods. As a result of their floating exchange rate regimes, IT countries suffered sharp real depreciations which were not associated with a greater perception of risk by markets (Filho 2011). It is argued that floating exchange rates were allowed to depreciate significantly thereby helping mitigate the deterioration of the external balance especially for developing countries (Didier et al. 2012, pp.2052-2077). Spiegel (2012) found that IT is associated with reduced current and capital account volatility during and after the GFC. Recent research also suggests that IT increases external reserve accumulations in developing countries and reduces the country risk premium (Lin, 2010, pp.195-199; Fouejieu and Roger, 2013) and IT countries experience lower exchange rate volatility and fewer sudden stops of capital flows than their counterparts (Rose, 2007, pp.663-681).

The results of our estimated models suggest that developing IT countries had superior macroeconomic performances and that they appear to have outperformed their advanced peers in handling the GFC under IT framework. Therefore, their economies have contracted substantially less than those of advanced IT countries in the aftermath of the GFC. Based on our findings, we argue that the greater performance of these economies is explained by their different motivations for adopting IT and thereby a fundamental change in their policy behaviour relative to the past. The choice of IT in advanced countries reflected their desire to achieve inflation targets, to institutionalise price stability and credibility. Additionally, generally in contrast to developing countries, both advanced IT and non-IT countries were not suffering from high inflation, low credibility, weak institutional structure or macroeconomic instability. The GFC found these countries with low policy space to cope with financial instability and the destabilising effects of the crisis.

From the point of view of developing countries, the choice of IT is crisis-driven or related to their aban- donment of exchange rate targeting (Freedman and Laxton, 2009). Their adoption of the IT framework was part of a broader process of macroeconomic stabilisation and structural adjustment programmes with the IMF. In the early days of IT, advanced countries have outperformed developing countries with respect to the volatility of inflation and GDP growth. These results are attributed to their fragile institutional structure and vulnerability to external shocks (Fraga et al., 2003). However, by moving to fullfledged IT, associated with its institutional and other requirements such as central bank independence, absence of fiscal dominance, floating exchange rates, developing IT countries have improved their institutional structure, graduated from pro-cyclical monetary and fiscal policy and have had a greater ability to conduct countercyclical policies (Frankel et al., 2011; Didier et al., 2012, pp.2052-2077; Vegh and Vulletin, 2012). The GFC found these countries with more policy space and required credibility to cope with the adverse effects of the crisis. Accordingly, among other factors, IT framework and a countercyclical fiscal policy have been the most important factors behind the perceived improvement in their macroeconomic performance (Coulibaly 2012; IMF, 2012, pp.129-171).

Policy responses to the crisis and the differences of the macroeconomic performance between advanced and developing IT countries also posed diverse challenges to the IT. The recovery in economic activity in advanced countries remained weak and growth problems and fiscal constraints persisted. To tackle these problems, authorities in the advanced countries stated that the easing of monetary policy would continue as long as necessary to reduce unemployment. While monetary easing in advanced countries led to a surplus of global liquidity, it also fuelled capital flows to developing countries (Bank for International Settlements, 2010) and formed a new global policy environment which was called as New Normal (ElArian 2010). Although developing IT countries have performed better in the aftermath of the crisis, they were forced to address the negative effects of capital flows and sought to compromise between price and financial stability under IT. These developments produced some insights about the future of IT, as King (2009) stated: "Inflation targeting is a necessary but not sufficient condition for stability in the economy as a whole. When a policy is necessary but not sufficient, the answer is not to abandon, but to augment it". 


\section{Conclusion}

The GFC that began in the USA in August 2007 has raised important questions concerning the conduct of monetary policy under IT. In contrast to previous literature on the topic, this paper compares the performance of advanced and developing IT countries rather than IT and non-IT countries. By focusing on 6 advanced and 14 developing IT countries, we analyse their macroeconomic performance before and after the GFC and seek to assess the effectiveness of IT framework in both country groups when confronting a serious shock. We used panel data methodology to compare the performance of advanced and developing IT countries. Based on the results of our empirical analysis, developing IT countries have outperformed their advanced peers in the aftermath of the crisis. Additionally, these countries appear to have coped better with the GFC under the IT framework. They had more policy space and required credibility to cope with the adverse effects of the crisis relative to their advanced peers. We argue that by moving to full-fledged IT, these countries have improved their institutional structure and resilience to the external and domestic shocks. Therefore, the IT framework and countercyclical fiscal policy have been the most important factors behind the perceived improvement in their macroeconomic performance.

The GFC also posed diverse challenges to the IT countries. The crisis accentuated the fact that price stability is not enough to secure financial stability and better macroeconomic performance. Thus, the main issue for the future of IT is to improve it by incorporating financial stability.

\section{References}

Angeriz, A., Arestis, P. (2008). Assessing Inflation Targeting through Intervention Analysis. Oxford Economic Papers, 60, 293-317.

Arestis, P. (2012). A Historical, Theoretical and Empirical Perspective on Inflation Targeting in Hagen M. Kramer, Heinz D. Kurz \& Hans-Michael Trautwein, (Eds). Macroeconomics and the History of Economic Thought Festschrift in Honour of Harald Hagemann, 196-208. New York: Routledge.
Arestis, P., Caporale, G. M., Cippolini, A. (2002). Does Inflation Targeting Affect the Trade Off Between Output Gap and Inflation Variability. The Manchester School, 70, 528-545.

Arestis, P., Sawyer, M. (2010). What Monetary Policy After the Crisis?. Review of Political Economy, 22, 499-515.

Arestis, P., Sawyer, M. (2013). Moving from Inflation Targeting and Incomes Policy. Panoeconomicus, 60, 1-17.

Ball, L. (2010). The Performance of Alternative Monetary Regimes. National Bureau of Economic Research Working Paper, 16124.

Ball, L., Sheridan, N. (2005). Does Inflation Targeting Matter?. in Ben S. Bernanke \& Michael Woodford, (Eds). The Inflation-Targeting Debate, 249-282. Chicago: University of Chicago Press.

Bank for International Settlements. (2010). $80^{\text {th }}$ Annual Report.

Bank of Japan. (2012). The Price Stability Goal in the Medium to Long Term. February 14, 2012, Retriewed 29.01.2015, from http://www.boj.or.jp/en/announcements/release_2012/k120214b.pdf.

Batini, N., Laxton, D. (2007). Under What Conditions Can Inflation Targeting be Adopted? The Experience of Emerging Markets. in Frederic S. Mishkin, Klaus Schmidt-Hebbel \& Norman Loayza, (Eds). Monetary Policy Under Inflation Targeting, p. 467506. Central Banking, Analysis and Economic Policies Book Series. Santiago: Banco Central de Chile.

Bernanke, B. S., Laubach,T., Mishkin, F. S. \& Posen, A.S. (1999). Inflation Targeting: Lessons from International Experience. Princeton: Princeton University Press.

Bernanke, B.S. (2004). The Great Moderation. Remarks at the meetings of the Eastern Economic Association, Washington, February 20, 2004. 
Bernanke, B.S. (2003). A Perspective on Inflation Targeting. Remarks at the Annual Washington Policy Conference of the National Association of Business Economists, Washington, March 25, 2003.

Blanchard, O. (2009). The State of Macro. Annual Review of Economics, 1, 209-228.

Blanchard, O., Del'Ariccia, G., Mauro, P. (2010). Rethinking Macroeconomic Policy. Journal of Money, Credit and Banking Supplement, 42, 199-215.

Blanchard, O. J., Mitali D., Faruqee, H. (2010). The Initial Impact of the Crisis on Emerging Market Countries. Brookings Papers on Economic Activity, 41, 263-307.

Borio, C. (2011). Central Banking Post-Crisis: What Compass for Uncharted Waters?. Bank for International Settlements Working Papers, 353.

Borio, C., White, W. (2004). Whither Monetary and Financial Stability? The Implications of Evolving Policy Regimes. Bank for International Settlements Working Papers, 147.

Borio, C., Disyatat, P. (2009). Unconventional Monetary Policies: An Appraisal. Bank for International Settlements Working Papers, 292.

Broto, C. (2011). Inflation targeting in Latin America: Empirical Analysis Using GARCH Models. Economic Modelling, 28, 1424-1434.

Buiter, W. (2009). The Unfortunate Uselessness of Most State of the Art Academic Monetary Economics. March 3, 2009. Retriewed 29.01.2015, from http://blogs.ft.com/maverecon/2009/03/theunfortunate-uselessness-of-most-state-of-the-artacademic-monetary-economics/.

Bullard, J. B. (2012). Inflation Targeting in the USA. Speech at the Union League Club of Chicago. Chicago, February 6, 2012.

Cameron, A. C. \& Trivedi, P. K. (2006). Microeconometrics Methods and Applications. Cambridge: Cambridge University Press.
Carney, M. (2012). Guidance. Remarks at the CFA Society, Toronto. December 11, 2012. Retriewed 29.01.2015, from http://www.bankofcanada. ca/2012/12/speeches/guidance/.

Cecchetti, S. G., Ehrmann, M. (2002). Does Inflation Targeting Increase Output Volatility? An International Comparison of Policymakers' Preferences and Outcomes in Norman Loayza \& Klaus SchmidtHebbel, (Eds). Monetary Policy: Rules and Transmission Mechanisms, 247-274. Central Banking, Analysis and Economic Policies Book Series. Santiago: Banco Central de Chile.

Claessens, S., Dell'Ariccia, G., Igan, D., Laeven, L. (2010). Cross-Country Experiences and Policy Implications from the Global Financial Crisis. Economic Policy, 25, 267-293.

Clarida, R., Gali, J., Gertler, M. (1999). The Science of Monetary Policy: A New Keynesian Perspective. Journal of Economic Literature, 37, 1661-1707.

Coulibaly, B. (2012). Monetary Policy in Emerging Market Economies: What Lessons from the Global Financial Crisis. Board of Governors of the Federal Reserve System International Finance Discussion Papers, 1042.

Decressin, J., Laxton, D. (2009). Gauging Risks for Deflation, International Monetary Fund Staff Position Note, $09 / 01$.

Didier, T., Constantino, H., Schmukler, S.L. (2012). How Resilient and Countercyclical were Emerging Economies During the Global Financial Crisis?. Journal of International Money and Finance, 31, 2052-2077.

Dueker, M. J., Fischer, A. M. (2006). Do Inflation Targeters Outperform Non-Targeters. Federal Reserve Bank of St. Louis Review, 84, 431-450.

El-Arian, M.A. (2010). Navigating the New Normal in Industrial Countries. The Per Jacobsson Lecture, Washington.

Erlat, H. (1997). Panel Data: A Selective Survey. Yapi Kredi Research Department Discussion Series, No. 97-04. 
Federal Open Market Committee. (2012) Press Release. January 25, 2012. Retriewed 29.01.2015, from http://www.federalreserve.gov/newsevents/press/ monetary/20120125c.htm.

Filho, I. C. (2011). 28 Months Later: How Inflation Targeters Outperformed Their Peers in the Great Recession. The B. E. Journal of Macroeconomics, 11, 1-44.

Fouejieu, A. A, Roger, S. (2013). Inflation Targeting and Country Risk: an Empirical Investigation. International Monetary Fund Working Paper, 13/21.

Fraga, A., Goldfajn, I, Minella, A. (2003). Inflation Targeting in Emerging Market Economies. National Bureau of Economic Research Working Paper, 10019.

Frankel, J., Vegh, C., Vulletin, G. (2011). On Graduation from Fiscal Procyclicality. National Bureau of Economic Research Working Paper, 17691.

Frankel, J. (2012). Inflation Targeting Is Dead: Long Live Nominal GDP Targeting. June 19, 2012. Retriewed 29.01.2015, from http://www.voxeu.org/article/inflation-targeting-dead-long-live-nominalgdp-targeting.

Frappa, S., Mésonnier, J. S. (2010). The Housing Price Boom of the Late 1990s: Did Inflation Targeting Matter. Journal of Financial Stability, 6, 243-254.

Freedman, C., Laxton, D. (2009). Why Inflation Targeting?. International Monetary Fund Working Paper, 09/86.

Friedman, B. F. (2004). Monetary Policy for Emerging Market Economies: Beyond Inflation Targeting. Macroeconomics and Finance in Emerging Market Economies, 1, 1-12.

Gerlach, S., Giovannini. A, Tille,C., Viñals, J. (2009). Are the Golden Years of Central Banking Over? The Crisis and the Challenges. London: Centre for Economic Policy Research.
Goncalves, C. E. S., Salles, J. M. (2008). Inflation Targeting in Emerging Economies: What do the Data Say. Journal of Development Economics, 85, 312318.

Goncalves, C. E. S., Carvalho, A. (2009). Inflation Targeting Matters: Evidence from OECD Economies' Sacrifice Ratios. Journal of Money, Credit and Banking, 41, 233-243.

Grauwe, P. (2007). There is more to Central Banking than Inflation Targeting. Nowember 14, 2007. Retriewed 29.01.2015, from http://www.voxeu.org/ article/subprime-crisis-time-inflation-targetingrethink.

Gudmundsson, M. (2010). Challenges to Inflation Targeting: Raising Some Issues. Bank for International Settlements Papers, 51.

Gujarati, D.N. (2003). Basic Econometrics. New York: McGraw-Hill.

Gürkaynak, R. S., Levin, A. T., Marder, A. N., Swanson, A. T. (2007). Inflation Targeting and the Anchoring of Inflation Expectations in the Western Hemisphere in Frederic S. Mishkin, Klaus SchmidtHebbel \& Norman Loayza, (Eds). Monetary Policy Under Inflation Targeting, p. 415-465. Central Banking, Analysis and Economic Policies Book Series. Santiago: Banco Central de Chile.

Habermeier, K., Ötker-Robe, I., Jacome, L., Giustiniani, A., Ishi, K., Vávra, D., Kışınbay, T., Vazquez,F. (2009). Inflation Pressures and Monetary Policy Options in Emerging and Developing CountriesA Cross Regional Perspective. International Monetary Fund Working Paper, 09/1.

Hildebrand, P. (2011). Introduction of a Minimum Swiss Franc Exchange Rate against the Euro. Short statement, 6 September, 2011. Retrieved 29.01.2015, from http://www.snb.ch/en/

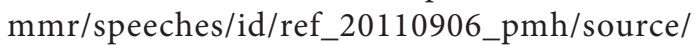
ref_20110906_pmh.en.pdf. 
Hsiao, C. (2003). Analysis of Panel Data. Cambridge: Cambridge University Press.

Hume, M., Sentence, A. (2009). The Global Credit Boom: Challenges for Macroeconomics and Policy. Journal of International Money and Finance, 28, 1426-1461.

International Monetary Fund. (2005). World Economic Outlook Building Institutions, Washington: International Monetary Fund.

International Monetary Fund. (2012). World Economic Outlook Coping with High Debt and Sluggish Growth, Washington: International Monetary Fund.

Issing, O. (2012). The Mayekawa Lecture: Central Banks-Paradise Lost. Monetary and Economic Studies, 30, 55-74.

Ito, T. (2010). Monetary Policy and Financial Stability: Is Inflation Targeting Passé?. Asian Development Bank Economics Working Paper Series, 206.

Johnson, D. R. (2002). The Effect of Inflation Targeting on the Behaviour of Expected Inflation: Evidence From An 11 Country Panel. Journal of Monetary Economics, 49, 1493-1519.

King, M. (2009). Speech at the Lord Mayor's Banquet for Bankers and Merchants of the City of London at the Mansion House, London, June 17, 2009.

Krause, S., Mendez, F. (2008). Institutions, Arrangements and Preferences for Inflation Stability: Evidence and Lessons from a Panel Data Analysis. Journal of Macroeconomics, 30, 282-307.

Lane, P. R., Milesi-Ferretti, G. M. (2010). The CrossCountry Incidence of the Global Crisis. International Monetary Fund Working Paper, 10/171.

Lanzafame, M., Nogueira Jr, R. P. (2011). Credibility in Emerging Economies: Does Inflation Targeting Matter?. The Manchester School, 79, 1080-1098.
Lee, W. S. (2011). Comparative Case Studies of the Effects of Inflation Targeting in Emerging Economies. Oxford Economic Papers, 63, 375-397.

Leijonhufvud, A. (2008). Central Banking Doctrine in Light of the Crisis. May 14, 2008. Retrieved 29.01.2015, from http://economistsview.typepad. com/economistsview/2008/05/central-banking. html.

Levin, A. T., Natalucci, F. M., Piger, J. M. (2004). The Macroeconomic Effects of Inflation Targeting. Federal Reserve Bank of St. Louis Review, 86, 51-80.

Lin, S., Ye, H. (2007). Does Inflation Targeting Really Make a Difference? Evaluating the Treatment Effect of Inflation Targeting in Seven Industrial Countries. Journal of Monetary Economics, 54, 2521-2533.

Lin, S., Ye, H. (2009). Does Inflation Targeting Make a Difference in Developing Countries?. Journal of Development Economics, 89, 118-123.

Lin, S. (2010). On the International Effects of Inflation Targeting. The Review of Economics and Statistics, 92, 195-199.

Louis, R. J., Balli, F. (2013). Low-Inflation-Targeting Monetary Policy and Differential Unemployment Rate: Is Monetary Policy to be Blamed for the Financial Crisis? Evidence from Major OECD Countries. Economic Modelling, 30, 546-564.

Mátyás, L. \& Sevestre, P. (1996). The Econometrics of Panel Data. Dordrecht, the Netherlands: Kluwer Academic Publisher.

Mendonça, H. F. (2007). Empirical Evidence from Fourteen Countries with Explicit Inflation Targeting. Applied Economics Letters, 14, 573-576.

Mendonça, H. F., Guimarães, G. J. S. (2012). Is Inflation Targeting a Good Remedy to Control Inflation?. Journal of Development Economics, 98, 178-191.

Mishkin, F. S. (2011). Monetary Policy Strategy: Lessons from the Crisis. National Bureau of Economic Research Working Paper, 16755. 
Mishkin, F.S. \& Schmidt-Hebbel,K. (2007). Does Inflation Targeting Make a Difference in Frederic S. Miskin, Klaus Schmidt-Hebbel \& Norman Loayza, (Eds). Monetary Policy under Inflation Targeting, p. 291-372. Central Banking, Analysis and Economic Policies Book Series. Santiago: Banco Central de Chile.

Neumann, M. J., Hagen, J. (2002). Does Inflation Targeting Matter. Federal Reserve Bank of St. Louis Review, 84, 127-148.

O'Hara, P. A. (2011). International Subprime Crisis and Recession: Emerging Macroprudential, Monetary, Fiscal and Global Governance. Panoeconomicus, 58, 1-17.

Ostry, J. D., Ghosh, A. R., Chamon, M., Qureshi, M. S. (2012). Tools for Managing Financial Stability Risks from Capital Inflows. Journal of International Economics, 88, 407-421.

Posen, A.S. (2009). Inflation Targeting after the Bubble. Austrian National Bank's 37th Economics Conference, Vienna.

Primus, K., Reshma, M. (2011). An Empirical Analysis of the Inflation Targeting Framework in a Time of Financial and Economic Crisis. Business, Finance and Economics in Emerging Economies, 6, 136-159.

Rasche, R. H., Williams,M. (2007). The Effectiveness of Monetary Policy. Federal Reserve Bank of St. Louis Review, 89, 447-489.

Roger, S. (2010). Inflation Targeting at Twenty: Achievements and Challenges in David Cobham, Øyvind Eitrheim, Stefan Gerlach and Jan F. Qvigstad, (Eds). Twenty Years of Inflation Targeting Lessons Learned and Future Prospects, p. 25-56. New York: Cambridge University Press.

Rose, A. K. (2007). A Stable International Monetary System Emerges: Inflation Targeting is Bretton Woods, Reversed. Journal of International Money and Finance, 26, 663-681.

Rose, A. K., Spiegel,M. M. (2011). Cross-country Causes and Consequences of the 2008 Crisis: An Update. European Economic Review, 55, 309-324.
Samaryna, H., Haan, J. (2011). Right on Target: Exploring the Determinants of Inflation Targeting Adoption, De Nederlandsche Bank Working Paper, 321.

Siklos, P. L. (2010). Inflation Targeting: It's Not Broke, It Doesn't Need Fixing, But Can It Survive?. Journal of International Commerce, Economics and Policy, $1,59-80$.

Spiegel, M. M. (2012). Monetary Regimes and Capital Account Volatility Before and After the Global Financial Crisis, in Victor Pontines and Reza Siregar, (Eds). Exchange Rate Appreciation, Capital Flows and Excess Liquidity: Adjustment and Effectiveness of Policy Responses, p. 115-173. Malaysia: The South East Asian Central Banks (SEACEN) Centre.

Stiglitz, J.E. (2008). The Failure of Inflation Targeting. May 6, 2008. Retrieved 29.01.2015, from http:// www.project-syndicate.org/commentary/thefailure-of-inflation-targeting.

Stiglitz, J. E. (2011). Rethinking Macroeconomics: What Failed, and How to Repair It. Journal of the European Economic Association, 9, 591-645.

Stock, J.H. \& Watson, M. W. (2003). Has the Business Cycle Changed: Evidence and Explanations. Federal Reserve Bank of Kansas City Jackson Hole Symposium. Kansas.

Stock, J. H. \& Watson, M. W. (2007). Introduction to Econometrics. Boston: Pearson Addison Wesley.

Svensson, L.E.O. (2002). Monetary Policy and Real Stabilization. Federal Reserve Bank of Kansas City Jackson Hole Symposium, Kansas.

Svensson, L.E.O. (2009). Flexible Inflation Targeting: Lessons from the Financial Crisis. Speech at the workshop "Towards a new framework for monetary policy? Lessons from the crisis" organized by De Nederlandsche Bank, Amsterdam, September 21, 2009.

Svensson, L.E.O. (2010). Monetary Policy after the Financial Crisis. Speech at the IJCB Conference, Bank of Japan, September 17, 2010. 
Taylor, J. B. (2009). Economic Policy and the Financial Crisis: An Empirical Analysis of What Went Wrong. Critical Review, 21, 341-364.

Truman, E. M. (2003). Inflation Targeting in the World Economy. Washington: Institute of International Economics.

Vega, M., Winkelried, M. (2005). Inflation Targeting and Inflation Behaviour Successful Story?. International Journal of Central Banking, 1, 153-175.

Vegh, C., Vuletin,G. (2011). Overcoming the Fear of Free Falling: Monetary Policy Graduation in Emerging Markets. National Bureau of Economic Research Working Paper, No. 18175.
Wagner, H. (2010). The Causes of the Recent Financial Crisis and the Role of Central Banks in Avoiding the Next One. International Economics and Economic Policy, 7, 63-82.

Walsh, C. E. (2009). Inflation Targeting: What Have We Learned?. International Finance, 12, 195-233.

Walsh, C. E. (2011). The Future of Inflation Targeting. The Economic Record, 87, 23-36.

Willard, L. B. (2011). Does Inflation Targeting Matter? A Reassessment. Applied Economics, 44, 22312244.

Woodford, M. (2012). Inflation Targeting and Financial Stability. Sveriges Riksbank Economic Review, $1,7-32$. 